\title{
Diamond Occurrences in Kimberlites and Lamproites from Phanerozoic Mobile Belts on Example of the Timans, Urals and Ouachita
}

Mal'kov, B.A., Malyshev, N.A.

Institute of Geology, Komi Science Centre, Ural Division of RAS, Syktyvkar, 167610, Russia

According to Clifford rule, diamond-bearing kimberlites are encountered only within cratons, although areas of kimberlite volcanism can extend to adjacent mobile belts as well. Diamondbearing kimberlites and lamproites suggest presence of lithospheric roots under the cratons, going to the depth of over $150 \mathrm{~km}$. They provide disintegrated diamond-bearing matter in the form of mantle-derived xenoliths and individual xenocrysts, for kimberlite and lamproite magmas. Loss of the diamond-bearing roots by the cratons as a result of their degradation or tectonic erosion, account for kimberlites and lamproites containing no diamonds (Mal'kov, 1997).

Diamond-bearing diatremes in Phanerozoic mobile belts are found only as exceptions and deserve a special study and explanation. To these belong diatremes from the Ouachita, Timans and Urals. Diamond-bearing lamproites from Prairie-Creek, Arkansas, with the absolute age of $106 \mathrm{Ma}$, cut through the Paleozoic rocks of the Ouachita, which thrusted onto the southern part of North American craton during Alleghanian orogeny and partially overlay the Fore-Ouachita sedimentary basin of Arkoma. Besides, the lamproites intrude a nearly horizontal lying Lower Cretaceous sedimentary clastics, nonconformable with the dislocated Early- and Mid-Paleozoic sedimentary, metamorphic and igneous rocks of the Ouachita orogen and Proterozoic (1.3 to $1.85 \mathrm{Ga})$ metamorphic rocks (Viele and Thomas, 1989; Nicholas and Waddell, 1989).

The lamproites are located within the Ouachita orogen, $100 \mathrm{~km}$ south of the North American carton's border. Since the lamproite diamonds are of Archean age (3.1 Ga) (Melton and Giardini, 1980), it is clear that the lamproite area of Prairie-Creek is also underlain by subcraton diamondbearing lithospheric mantle, although it underwent a strong metasomatic alteration 1200 mln years ago (Lambert et al., 1995). Diamond-bearing lamproites in Prairie-Creek in the Ouachita mobile belt is such an exception of Clifford rule which actually confirms it.

Mid-Timanian diatremes from olivine melilitites of the Early Devonian age (400 Ma) contain no diamonds. However, found in the immediate vicinity is a Late Eifelian diamond-bearing placer of the Ichetyu river, which suggests existence of unknown diamond-bearing diatremes of the same Early Devonian age (Mal'kov and Holopova, 1995). Volsko-Vym ridge made by Riphean terrigenous deposits dislocated during the Cadomian orogeny, is situated $10-30 \mathrm{~km}$ to the east of than the regional zone of Late Riphean bioherm (stromatolithic) dolomites which at once marked the border of the Late Precambrian shelf of the East European Platform. The platform character of Late Riphean and Vendian magmatism in the Mid-Timans, from Chetlasky Kamen in the west to Volsko-Vym ridge in the east, indicates the presence of a deep Karelian crystalline basement slightly affected by Cadomian orogeny. Zirkon ages suggest that the Early Cambrian granite magmatism manifested itself 555-560 mln years ago only in the eastern, presently buried zone of the Timans. In the Mid-Timans, the platform character of magmatism is also preserved in Paleozoic. Early Devonian (400 Ma) witnessed formation of olivine melilitites diatremes with abundant rock and mineral inclusions derived from the Early Proterozoic subcraton lithospheric mantle. Karelian lithospheric roots under the Timans ridge as well as diamond-bearing placers found close to the 
known diatremes of the Umba field are a good base to predict diamond deposits of kimberlite and lamproite type in the Mid-Timans.

Tectonic movements in passing from Middle to Late Devonian gave rise to a system of troughs extending along strike, filled with products of Pashiyskian basalt volcanism and Frasnian sediments, which overlay and sealed both diamond-bearing and diamond-free diatremes, as in the case of the Umbinskaya pipe. A system of oblique and along strike reverse faults and overthrusts was formed during Early Kimmerian compression, which accounts for the modern structure of the Timans. In the uplifted blocks, the diatremes and Eifelian diamond-bearing placers turned out to be partially or fully eroded, their diamond-bearing material redeposited.

In Poludov uplift in the Urals, Takatinskaya diamond-bearing terrigenous deposits of the regressive stage of the Emsian act as the chief intermediate diamond traps, being the source for modern and quaternary alluvial as well as proximal placers. Concentrated here are Bolsheshugor, Severokolchim and Bolshekolchim diamond placers and deposits of Rassolninskaya and Ilyavozhskaya depressions. Prior to Permian, platform sediments had accumulated in the zone of Poludov uplift and they were subsequently buried under molasses accumulated in a foredeep. In the west, the uplift is bordered by an arched (in plan) thrust zone, known as Krasnovishersk-Nyrob thrust. Found in its front parts are Poludov and Kolchim structures, the largest in Poludov uplift, with Riphean sediments exposed in their cores. In the east, the uplift is overlain by a branch of the Main West Uralian Thrust.

The Late Paleozoic fold and thrust zone in the Urals as well as the Early Cambrian one in the Timans, were rejuvenated by old Kimmerian dislocations, then they were levelled down by intense erosion. A new uplift of the Urals began only in Late Oligocene and has been going on up till now (Puchkov, 1997). The dislocated Takatin deposits were washed out and served as sources for quaternary and modern alluvium as well as proximal placers. The source areas for Takatin paleoplacers are not known, however, they must have been of the Early Devonian age and located to the west and north-west from the area of the reported placers, i.e. on the Russian Plate and the Timans.

The top of the lithospheric mantle is somewhat lifted under Poludov uplift and lies about $40 \mathrm{~km}$ deep. Krasnovishersk thrust, bordering the uplift in south-west is observed by DSS not only in the sedimentary cover but also in the granulite-basite layer of the Earth's crust to $25 \mathrm{~km}$ deep, at which level it stretches against the zone of deep faults of western dip observed from Conrad surface to the mantle. Krasnovishersk-Nyrob thrust with the amplitude of about 10-20 km overlay the likely zone of pre-Takatinskaya diamond-bearing kimberlite diatreme occurrence, thus creating a severe problem for its prospecting. Lately, it has been reported that the rich diamond-bearing depressions within the area of Poludov uplift (Rassolninskaya, Iljavozhskaya, etc.) are not filled with normal quaternary sediments, instead they are filled with hypergenically altered volcano-clastic diamondbearing rocks of lamproite or other nature called "rybalites" by local geologists.

The "rybalites" discoverer and his colleagues (Rybalchenko A. and Rybalchenko T., 1997; Chaikovsky, 1997) report the following: (1) Parents diamond-bearing bodies of the diatreme, sill, dike, vein and stockwork types are composed of argillized tuffisites, xenotuffisites and tuff breccias of alkaline-ultrabasic (?) composition. (2) Diamond-bearing bodies are found in the allochthone of Krasnovishersk-Nyrob thrust along the Paleozoic necklace-shaped border of Kolchim and Tulym- 
Parma anticlines, complicated by a series of echelon-like bodies. (3) Formation of diamond-bearing volcanites and their bodies was preceded by thrusting. (4) Eruptions were presumably of phreatomagmatic character. (5) Presence of accessory pyropes and chromites of diamond association was observed in hypergenically altered volcano-clastic diamond-bearing rocks from Rassolninskaya deposit, on the other hand, melt spherules of silicate, oxide, sulphide and intermetallic composition, previously reported from a number of kimberlite diatremes in Yakutia, were found.

Evidence on the matter of the strongly altered "rybalites" is not sufficient for their accurate petrographic attribution. However, the major advance is the find of truly diamond-bearing volcanites in an unusual geological setting and their location in the Hercynian mobile belt of the Urals within marginal Krasnovishersk-Nyrob overthrust. It is underlain by Archean crystalline basement of the East-European Platform, as indicated by geophysical methods, with subcraton lithospheric mantle observed underneath the basement, with deep (over $150 \mathrm{~km}$ ) diamond-bearing lithospheric roots from which xenogenic diamond-bearing material is brought up by "rybalite" magmas to the post-Hercynian phase of kimberlite (?) volcanism.

The area of Poludov ridge is distinguished by two distinct epochs of productive volcanism in Phanerozoic: the one preceding folding (pre-Takatin) and following it (post-Permian). Takatin diamond-bearing placers of Emsian as well as Upper Eifelian littoral placers in the Mid-Timans are linked to Early Devonian diamond-bearing kimberlites synchronous with Timanian diatremes of the Umba field. The tectonic situation of post-Permian diamond-bearing "rybalites" occurrence is similar to the tectonic setting of Arkansas diamond-bearing lamproites in the Ouachita mobile belt. Both are located in marginal fold-and-thrust zones overlying adjacent cratons with preserved diamond-bearing lithospheric roots.

\section{References}

Chaikovsky, I. I., 1997, Typomorphism of minerals Rassolninskaya diamond deposit: Geology and useful minerals of the western Urals (proceedings of regional conference), Perm, p. 104-106 (in Russian).

Lambert, D. D., Shirey, S. B., and Bergman, S. C., 1995, Proterozoic lithospheric mantle source for the Prairie Creek lamproites: Re-Os and Sm-Nd isotopic evidence: Geology, 23, p. 273-276.

Ma'lkov, B. A., 1997, Geology and petrology of kimberlites: Nauka, St-Petersburg, 282 pp. (in Russian).

Mal'kov, B. A., and Holopova, E. B., 1995, Diatremes and diamond placers in the Middle Timans: Geoprint, Syktyvkar, 50 pp. (in Russian).

Melton, C. E., and Giardini, A. A.,1980, The isotopic composition of argon included in an Arkansas diamond and its signification: Geophys. Res. Lett., 7, p. 461-464.

Nicholas, R. L., and Waddell, D. E., 1989, The Ouachita system in the subsurface of Texas, Arkansas, and Louisiana: Hatcher, R. D., Jr., Thomas, W. A., and Viele, G. W., eds., The Geology of North America, v. F-2, The Appalachian-Ouachita Orogen in the United States: Boulder, Colorado, Geological Society of America, p. 661-672.

Rybalchenko, A. Ya., and Rybalchenko, T. M., 1997, A tentative model of location and formation of source diamond-bearing objects of Uralian type: Geology and useful minerals of the western Urals (proceedings of regional conference), Perm, p. 100-101 (in Russian).

Puchkov, V. N., 1997, Structure and geodynamics of the Uralian orogen: Orogeny Through Time: Geological Society Special Publication, 121, p. 201-236. 